\title{
Antagonistic activity expressed by Shigella sonnei: identification of a putative new bacteriocin
}

\author{
Mireille Ângela Bernardes Sousa1, Luiz de Macêdo Farias', Patrícia Luciana de Oliveira', \\ Jaqueline Silvana Moreira', Ana Carolina Morais Apolônio', Jamil Silvano Oliveira², \\ Marcelo Matos Santoro², Edilberto Nogueira Mendes³, Paula Prazeres Magalhães ${ }^{1 /+}$
}

\author{
${ }^{1}$ Departamento de Microbiologia ${ }^{2}$ Departamento de Bioquímica e Imunologia, Instituto de Ciências Biológicas \\ ${ }^{3}$ Departamento de Propedêutica Complementar, Faculdade de Medicina, Universidade Federal de Minas Gerais, Belo Horizonte, MG, Brasil
}

\begin{abstract}
Bacteriocins are antibacterial, proteinaceous substances that mediate microbial dynamics. Bacteriocin production is a highly disseminated property among all major lineages of bacteria, including Shigella. In this paper, we addressed the purification and characterisation of a bacteriocin produced by a Shigella sonnei strain (SS9) isolated from a child with acute diarrhoea. The substance was purified through ammonium-sulphate precipitation and sequential steps of chromatography. The intracellular fraction obtained at 75\% ammonium sulphate maintained activity following exposure to $\mathrm{pH}$ values from 1-11 and storage at $-80^{\circ} \mathrm{C}$ for more than two years and was inactivated by high temperatures and proteases. The molecular mass of the purified bacteriocin was determined by mass spectrometry to be $18.56 \mathrm{kDa}$. The $N$-terminal sequence of the bacteriocin did not match any other antibacterial proteins described. A putative new bacteriocin produced by S. sonnei has been detected. This bacteriocin may represent a newly described protein or a previously described protein with a newly detected function. Considering that SS9 expresses antagonism against other diarrhoeagenic bacteria, the bacteriocin may contribute to S. sonnei virulence and is potentially applicable to either preventing or controlling diarrhoeal disease.
\end{abstract}

Key words: Shigella sonnei - bacteriocin - colicin - antagonistic substance - acute diarrhoea

Bacteriocins are proteinaceous substances that are ribosomally synthesised by bacteria exhibiting antagonistic activity usually against organisms that are closely related to the producer strain. Bacteriocins were originally characterised in Escherichia coli and their production has been demonstrated in a large variety of both Gram-positive and Gram-negative bacterial strains (Daw \& Falkiner 1996, Riley \& Wertz 2002, Cascales et al. 2007).

Several enterobacteria, mainly E. coli, express antagonistic activity attributed to the production of two groups of bacteriocins that are differentiated by their molecular mass and other properties. According to Cascales et al. (2007), colicins are high-molecular-mass proteins ranging from $40-80 \mathrm{kDa}$ and their release is generally lethal for the producing strain. There are two groups of colicins. Group A colicins translocate across the outer membrane via the Tol system and group B colicins utilise the Ton-dependent system (Kolter \& Moreno 1992, Braun et al. 2002, Sharma et al. 2006).

By contrast, microcins are smaller peptides at $10 \mathrm{kDa}$ or less and their synthesis is non-lethal for the producing strain and non-SOS-inducible (Baquero \& Moreno 1984, Kolter \& Moreno 1992, Pons et al. 2002, Heng \& Jack

doi: 10.1590/0074-0276108062013008

Financial support: FAPEMIG, CNPq, TWAS, CAPES, PRPq-UFMG

+ Corresponding author: ppmagalhaes@ufmg.br

Received 16 November 2012

Accepted 10 July 2013
2006). According to a recent proposal, two major classes of microcins are classified. Class I corresponds to small peptides, less than $5 \mathrm{kDa}$, that are subjected to post-translational modifications. Class II includes larger microcins and is further divided into subclass IIa, which contains disulphide bonds, but do not undergo post-translational modification and subclass IIb, which gathers together those linear microcins that may carry a C-terminal posttranslational modification (Duquesne et al. 2007).

The best-known colicins are produced by E. coli. More than 30 colicin types have been described and all but one are plasmid-encoded (Smarda \& Smajs 1998, Cascales et al. 2007, Gillor et al. 2009). Shigella strains produce several colicins, including the well-characterised Js and U colicins originally expressed by Shigella sonnei and Shigella boydii, respectively (Smarda et al. 1987, Horák 1990, Smajs et al. 1997).

The synthesis of microcins is a more restricted phenomenon described almost exclusively for $E$. coli isolates. Fourteen microcins have been reported, of which seven are well studied. The production of microcins by Shigella strains has not been described (Pons et al. 2002, Duquesne et al. 2007).

Several human health, livestock, food and environmental applications for bacteriocins have been suggested, including the control of bacterial diarrhoeal disease (Murinda et al. 1996, Smarda \& Smajs 1998, Abriouel et al. 2010). Following the detection of bacteriocin expression, biochemical and physiological characterisation of the substance should be considered as a critical step that must precede any proposal for practical application. In this paper, we report the purification and partial characterisation of a new bacteriocin produced by an $S$. sonnei isolate. 


\section{SUBJECTS, MATERIALS AND METHODS}

Bacterial strains and media - S. sonnei strains, named SS9 and SS12, were isolated from children with acute diarrhoea who presented for treatment at Children's Hospital João Paulo II/Hospital Foundation of the State of Minas Gerais, Belo Horizonte, Brazil. The isolates were selected as producer and indicator strains based on data obtained from a previous screening of antagonistic activity in several S. sonnei isolates (Sousa et al. 2010).

The bacterial strains have been stored at $-80^{\circ} \mathrm{C}$ in Brucella Broth (Difco, Sparks, USA) with 10\% glycerol $(\mathrm{v} / \mathrm{v})$. Before each experiment, the strains were subcultured three times onto tryptic soy agar (TSA) (Difco). Antagonistic tests were performed by employing the following culture media at $\mathrm{pH}$ 7.0, based on previously reported results (Sousa et al. 2010): TSA, tryptic soy broth (TSB) (Difco) and TSB added with $0.7 \%$ Bacto agar (TSA-S) (Difco).

Evaluation of the homogeneity of the antagonistic activity expression - A 24-h broth culture of S. sonnei SS9 was serially diluted 10 -fold $\left(10^{-1}-10^{-8}\right)$ in sterile $0.85 \%$ saline and plated onto TSA with a Drigalski loop. After incubation for $24 \mathrm{~h}$ at $37^{\circ} \mathrm{C}$, the number of isolated colonies was estimated and culture plates presenting 30-300 colonies were selected for determining the percentage of positive clones. Antagonism expression by each colony was identified using the double-layer method (Booth et al. 1977). The assay was performed in duplicate.

Protein extraction - S. sonnei SS9 was cultivated in $1200 \mathrm{~mL}$ TSB at $37^{\circ} \mathrm{C}$ under aerobic conditions. After incubation for $12 \mathrm{~h}$, the culture was centrifuged at 5,000 $\mathrm{g}$ at $4^{\circ} \mathrm{C}$ for $30 \mathrm{~min}$. To obtain the extracellular fractions S-50 and S-75, supernatant proteins were precipitated with 50\% and $75 \%$ ammonium sulphate under constant slow stirring at $4^{\circ} \mathrm{C}$ (Green \& Hughes 1955). The precipitate was collected by centrifugation at the same conditions, suspended in $0.01 \mathrm{M}$ Tris-HCl pH 7.2 and dialysed (MEMBRACELL MC-18; Viskase, Darien, USA) against the same buffer at $4^{\circ} \mathrm{C}$ overnight. The intracellular fractions C-30, C-75 and C-100 were obtained by sonicating the cells suspended in the same buffer for 12 cycles of $1 \mathrm{~min}$ at $50 \mathrm{~W}$. Cellular disruption was checked by microscopy and the debris was removed by centrifugation at $25,410 \mathrm{~g}$ at $4^{\circ} \mathrm{C}$ for $30 \mathrm{~min}$. Next, the supernatant proteins were precipitated with $30 \%, 75 \%$ and $100 \%$ ammonium sulphate and processed as described for the extracellular fractions.

Antagonistic activity assays, titration of crude bacteriocin and determination of the protein concentration Antagonistic activity assays were performed by the overlay method (Booth et al. 1977). Ten-microlitres aliquots of a 24-h culture of the indicator strain (S. sonnei SS9) were transferred to $3.5 \mathrm{~mL}$ of TSA-S and the inoculums were poured over TSA plates. Ten microlitres of each intracellular and extracellular fraction were dropped onto the surface of the medium. Evidence of activity was provided by the presence of growth inhibition zones of the indicator strain after incubation for $24 \mathrm{~h}$ at $37^{\circ} \mathrm{C}$ under aerobic conditions. Active fractions were aliquoted and maintained at $-80^{\circ} \mathrm{C}$.
Titration of antagonistic activity was performed as previously described (Yamamoto et al. 2003). Aliquots of partially purified, active fractions were filtered and serially diluted two-fold in $0.01 \mathrm{M}$ Tris- $\mathrm{HCl} \mathrm{pH} 7.2$ on microtitration plates (Micrower Plate 96F; Greiner Bioone, Frickenhausen, Germany). Antagonistic activity assays were performed as described. The titre, expressed as arbitrary units of bacteriocin per millilitre $(\mathrm{AU} / \mathrm{mL})$, was defined as the reciprocal of the highest dilution that inhibited the indicator strain.

The protein concentration was determined according to the method of Bradford (1976), using bovine serum albumin (Sigma, St Louis, USA) as a standard.

Evaluation of antagonism expression along the growth curve - After determining the growth curve of $S$. sonnei SS9, antagonism expression along the curve was evaluated. Ten-microlitres aliquots of broth culture of the producer strain were taken at some points of the growth curve (lag, exponential and stationary phases) and used for testing antagonistic activity. The titration of inhibitory activity was performed as described.

Stability of the antagonistic substance - The effect of $\mathrm{pH}$, temperature and proteolytic enzymes on C-75 was evaluated by determining the preservation of antagonistic activity after each treatment, as described below.

$p H$ - Values ranging from 1.0-11.0 were tested using $\mathrm{KCl}-\mathrm{HCl}(\mathrm{pH} 1.0,2.0$ and 3.0), acetate $(\mathrm{pH} 4.0$ and 5.0), citrate (pH 6.0) and Tris- $\mathrm{HCl}(\mathrm{pH} 7.0,8.0,9.0,10.0$ and $11.0)$ buffers. C-75 (AU $=1,600 / \mathrm{mL})$ was diluted twofold in each filter-sterilised (Millex-GV $0.22 \mu \mathrm{m}$ PVDF; Millipore, County Cork, Ireland) buffer and the mixtures were incubated in a water bath at $37^{\circ} \mathrm{C}$ for intervals of $30 \mathrm{~min}, 1 \mathrm{~h}, 2 \mathrm{~h}, 3 \mathrm{~h}, 4 \mathrm{~h}, 5 \mathrm{~h}, 6 \mathrm{~h}, 7 \mathrm{~h}, 8 \mathrm{~h}$ and $24 \mathrm{~h}$ and $2,3,4,7,10,15,20,25$ and 30 days. Next, the mixtures were diluted two-fold (up to $1: 8$ ) in Milli- $Q^{\circledR}$ water (Millipore, Molsheim, France) and $10 \mu \mathrm{L}$ of each mixture was placed onto the indicator culture, as described. C-75, diluted C-75 (1:2-1:8 in Milli- ${ }^{\circledR}$ water) and buffers without C-75 were employed as controls.

Temperature - C-75 $(\mathrm{AU}=800 / \mathrm{mL})$ was treated at $-80^{\circ} \mathrm{C}, 5^{\circ} \mathrm{C}, 25^{\circ} \mathrm{C}, 37^{\circ} \mathrm{C}, 50^{\circ} \mathrm{C}, 70^{\circ} \mathrm{C}$ and $100^{\circ} \mathrm{C}$ for 20 min, $1 \mathrm{~h}, 2 \mathrm{~h}, 3 \mathrm{~h}, 4 \mathrm{~h}, 5 \mathrm{~h}, 6 \mathrm{~h}, 7 \mathrm{~h}, 14 \mathrm{~h}, 17 \mathrm{~h}$ and $24 \mathrm{~h}$, $2,3,4,7,10,12,15,20$ and 30 days and $2,3,4,6,12$, 18 and 24 months. After treatment, the temperature was set at $4^{\circ} \mathrm{C}$ and each aliquot was diluted 1:2, 1:4 and 1:8 in Milli- $Q^{\circledR}$ water and tested for antagonistic activity as previously described. Untreated crude and diluted C-75 aliquots were employed as controls.

Enzymes - $\alpha$-chymotrypsin, pepsin and trypsin (Sigma) diluted $(1.0 \mathrm{mg} / \mathrm{mL})$ in Tris-HCl $(0.02 \mathrm{M}, \mathrm{pH} 8.0)$, papain (Sigma) diluted $(1.0 \mathrm{mg} / \mathrm{mL})$ in phosphate buffer (0.05 M, pH 7.0) and proteinase K (Sigma) diluted (1.0 $\mathrm{mg} / \mathrm{mL})$ in Tris- $\mathrm{HCl}(0.02 \mathrm{M}, \mathrm{pH}$ 7.2) were employed. The enzyme solutions were sterilised by filtration through a $0.22-\mu \mathrm{m}$ membrane (Millex-GV). C-75 ( $\mathrm{AU}=3,200 / \mathrm{mL}$, $1.0 \mathrm{mg} / \mathrm{mL}$ ) was diluted 10 -fold in each enzyme solution and the mixtures were incubated at $37^{\circ} \mathrm{C}$ for $1 \mathrm{~h}$ and $4 \mathrm{~h}$. C-75, C-75 diluted in each buffer, each buffer alone and the enzyme solutions were used as controls. 
Bacteriocin purification - C-75 was submitted to ionexchange chromatography on a fast performance liquid chromatography (FPLC) system using a Mono- $\mathrm{Q}^{\mathrm{TM}}$ 5/50 GL column (GE Healthcare, Uppsala, Sweden) previously equilibrated with $0.02 \mathrm{M}$ Tris- $\mathrm{HCl}(\mathrm{pH} 8.0)$ and eluted with the same buffer using a gradient of $0-1.0 \mathrm{M} \mathrm{NaCl}$ in Tris- $\mathrm{HCl}(\mathrm{pH} 8.0)$. Aliquots of $1.5 \mathrm{~mL}$ were collected and tested for antagonistic activity. Active fractions were pooled, concentrated by lyophilisation and submitted to the next purification step. Gel filtration chromatography was performed on a FPLC system using a Superose 12 HR 10/30 column (GE Healthcare) equilibrated with $0.02 \mathrm{M}$ Tris- $\mathrm{HCl}(\mathrm{pH} 8.0)$ added with $0.2 \mathrm{M} \mathrm{NaCl}$ and the samples were eluted with the same buffer. Active aliquots were individually submitted to reverse-phase chromatography on a high performance liquid chromatography (HPLC) system using a LiChroCart ${ }^{\circledR} \mathrm{C} 18$ column $(250$ x $4.0 \mathrm{~mm})$ (Merck, Darmstadt, Germany). The mobile phases were $0.1 \%$ trifluoroacetic acid (TFA) and $80 \%$ aqueous acetonitrile solution containing $0.1 \%$ TFA. Aliquots were tested for antagonistic activity and the active fraction was lyophilised, suspended in Milli- ${ }^{\circledR}$ water and submitted to mass spectrometry.

Mass spectrometry - The molecular mass of purified bacteriocin was determined via mass spectrometry analysis. The sample was dissolved in saturated sinapinic acid $(5.0 \mathrm{mg}$ of aqueous solution of 3\% TFA: acetonitrile:water, 1:4:5, v/v) at a ratio of $1: 3(\mathrm{v} / \mathrm{v})$ sample:matrix, transferred in triplicate $(0.5 \mu \mathrm{L} /$ well $)$ for acquisition-board data MALDI (MTP AnchorChips 384 x 600; Bruker Daltonics, Billerica, USA) and maintained at room temperature. The molecular mass was determined with Autoflex ${ }^{\mathrm{TM}}$ III MALDI-TOF/TOF (Bruker Daltonics) operating in the positive linear mode. A linear calibration was performed using Protein Calibration Standard II (Bruker Daltonics).

Determination of the $N$-terminal amino acid sequence and sequence comparisons - The protein sequence was determined by Edman degradation using a Shimadzu PPSQ-21A automated protein sequencer (Shimadzu, Kioto, Japan). For the homology analysis, the amino acid sequences were compared with other protein sequences, using the BLAST network service.

\section{RESULTS}

Population homogeneity and evaluation of antagonistic activity along the growth curve - All S. sonnei SS9 isolates obtained from a single colony expressed antagonistic activity, indicating that the population is homogeneous.

Inhibitory activity was detected during the lag, exponential and stationary phases (Fig. 1). The highest titre of activity was observed in the early stationary phase of bacterial growth $(12,800 \mathrm{AU} / \mathrm{mL})$.

Antagonistic activity assays, titration of crude bacteriocin and determination of the protein concentration - Intracellular fractions C-30, C-75 and C-100 and extracellular fraction S-50 exhibited antagonistic activity. C-75 was selected for partial characterisation assays on the basis of the largest amount of extract obtained and the highest titre of antagonistic activity (Table I).
Stability of the antagonistic substance - The results describing the stability of C-75 are presented in Table II. C-75 maintained its activity for at least $24 \mathrm{~h}$ at $\mathrm{pH}$ values ranging from 1.0-11.0. At pH 5.0, 6.0 and 7.0, the inhibitory activity of the fraction was maintained for longer periods of time.

C-75 preserved its activity after incubation at temperatures ranging from $-80-50^{\circ} \mathrm{C}$ for at least $17 \mathrm{~h}$. The aliquot of the extract that is preserved at $-80^{\circ} \mathrm{C}$ is still active after more than 24 months.

The extract was completely inactivated by $1-\mathrm{h}$ exposure to proteinase $\mathrm{K}$, papain, pepsin, trypsin and $\alpha$-chymotrypsin.

Bacteriocin purification - In total, 37 fractions were obtained from ion-exchange chromatography. Among them, 17 exhibited antagonistic activity. Fractions 10-12 were combined and the originated pool was selected for the subsequent steps of the study because of its highest titre of antagonistic activity and the profile generated by gel filtration chromatography (Fig. 2A). Among the 27 fractions collected from gel filtration chromatography, eight (fractions 5-12) expressed activity and each was individually submitted to reverse-phase chromatography. Only one of the fractions derived from reversephase chromatography displayed activity (36.4-min

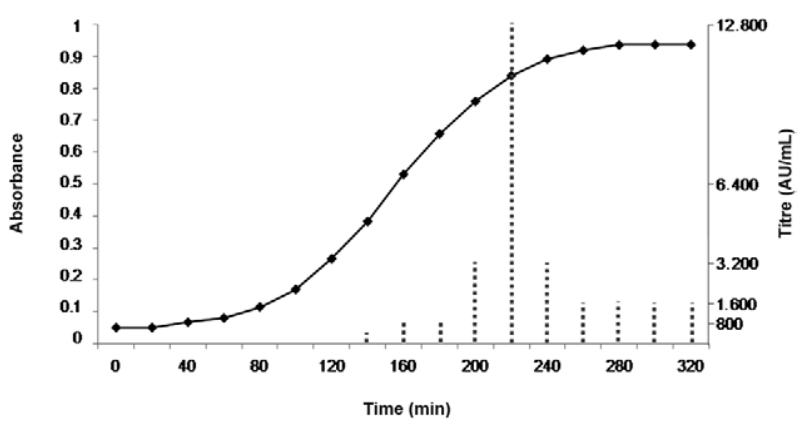

Fig. 1: expression of antagonistic activity along the growth curve of Shigella sonnei SS9. AU: arbitrary unit.

\section{TABLE I}

Titration and determination of protein concentration of active intracellular (C) and extracellular (S) fractions obtained after precipitation with $30 \%, 50 \%, 75 \%$ and $100 \%$ ammonium sulphate

\begin{tabular}{lcc}
\hline $\begin{array}{l}\text { Protein } \\
\text { fraction }\end{array}$ & $\begin{array}{c}\text { Bacteriocin activity } \\
(\mathrm{AU} / \mathrm{mL})\end{array}$ & $\begin{array}{c}\text { Protein concentration } \\
(\mathrm{mg} / \mathrm{mL})\end{array}$ \\
\hline C-30 & 102,400 & 1.12 \\
C-75 & $>838,860,800$ & 2.79 \\
C-100 & 400 & 0.23 \\
S-50 & 800 & 4.00 \\
\hline
\end{tabular}

Shigella sonnei SS9 grown in tryptic soy broth for $12 \mathrm{~h}$ at $37^{\circ} \mathrm{C}$. AU: arbitrary unit. 
TABLE II

Properties of the intracellular fraction obtained after precipitation with $75 \%$ ammonium sulphate (C-75)

\begin{tabular}{lc}
\hline Treatment & Period of time \\
\hline $\mathrm{pH}\left(37^{\circ} \mathrm{C}\right)$ & \\
$1.0,2.0,9.0,10.0,11.0$ & $24 \mathrm{~h}$ \\
3.0 & 3 days \\
$4.0,8.0$ & 4 days \\
$5.0,6.0$ & 25 days \\
7.0 & 20 days \\
Temperatures $\left({ }^{\circ} \mathrm{C}\right)$ & \\
100,70 & 20 min \\
50 & 17 days \\
37,25 & 20 days \\
5 & 180 days \\
-80 & $>24$ months \\
\hline
\end{tabular}

retention time) (Fig. 2B). At the end of the sequential purification steps, $22.2 \mu \mathrm{g}$ of purified protein (800 AU/ $\mathrm{mL}$ ) was obtained. Although a high specific activity was recovered, an extremely low percent yield was observed (Table III).

Mass spectrometry - Analysis by spectrometry revealed that the estimated average molecular mass of the bacteriocin was $18.56 \mathrm{kDa}$. Fig. $2 \mathrm{C}$ depicts the $+1,+2$ and +3 charged species of the purified protein.

Determination of the $N$-terminal amino acid sequence - N-terminal amino acid sequencing yielded the following sequence: Ser - Tre - Ala - Lys - Leu - Val - Lys - Ser - Lys - Ala - Tre - Asn - Leu - Leu - Tyr - Tre - Arg Asn - Asp - Val. The sequence displayed identity with 20 different proteins (100\% of identity with 8 proteins, $90 \%$ identity with 6 proteins and $80 \%$ and $75 \%$ identity with 3 proteins each) that seem to be associated with DNA protection during starvation, particularly iron binding
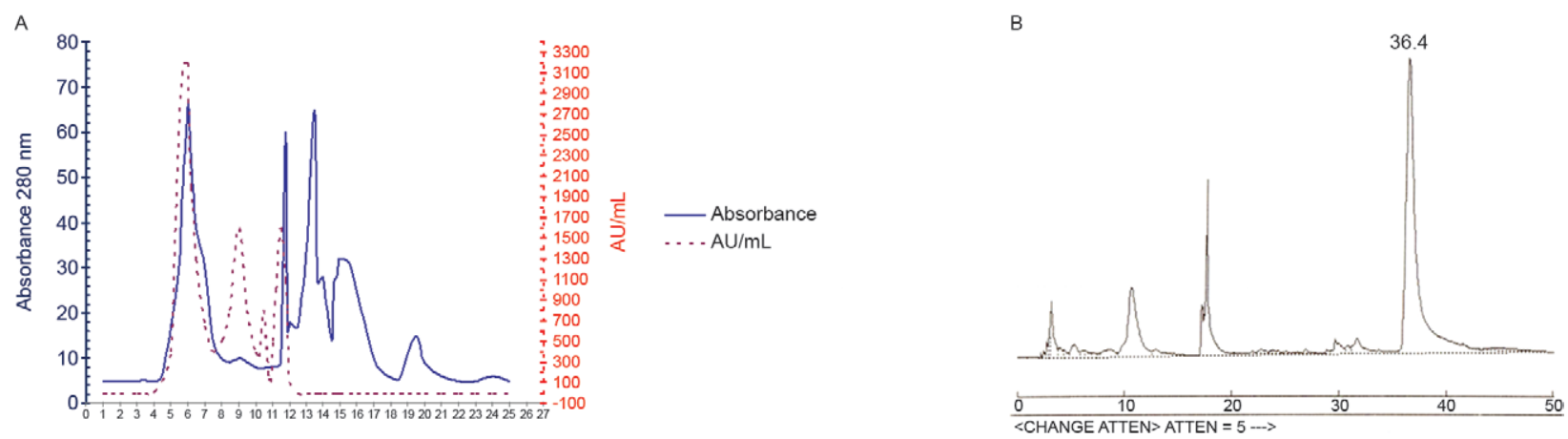

C

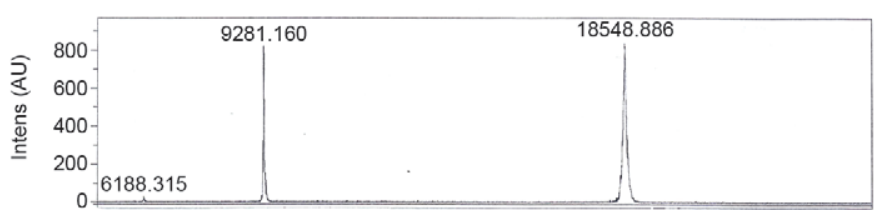

Fig. 2: purification steps of Shigella sonnei SS9 bacteriocin. A: gel filtration (fast performance liquid chromatogram; active fractions: 5-12); B: C18 reverse phase [high performance liquid chromatogram; mobile phase A: $0.1 \%$ trifluoroacetic acid (TFA); mobile phase B: $80 \%$ aqueous acetonitrile solution containing $0.1 \%$ TFA; linear gradient $0-100 \%$ of B solution in $30 \mathrm{~min}$ flow rate $1 \mathrm{~mL} / \mathrm{min}$, temperature $35^{\circ} \mathrm{C}$; active fraction: 36.4 min retention time]; $\mathrm{C}$ : mass spectrum of purified bacteriocin (the estimated average molecular mass of the protein was $18.56 \mathrm{kDa}$ ). AU: arbitrary unit.

\section{TABLE III}

Bacteriocin activity, protein concentration, specific activity, fold purification and percent yield during purification steps

\begin{tabular}{|c|c|c|c|c|c|c|}
\hline Protein fraction/obtained from & $\begin{array}{c}\text { Bacteriocin } \\
\text { activity } \\
(\mathrm{AU} / \mathrm{mL})\end{array}$ & $\begin{array}{l}\text { Total protein } \\
\text { concentration } \\
(\mathrm{mg})\end{array}$ & $\begin{array}{l}\text { Volume } \\
\text { (mL) }\end{array}$ & $\begin{array}{l}\text { Specific activity } \\
\left(\mathrm{AU} / \mathrm{mL} \times \mathrm{mg}^{-1}\right)\end{array}$ & $\begin{array}{c}\text { Fold } \\
\text { purification }\end{array}$ & $\begin{array}{c}\text { Yield } \\
(\%)\end{array}$ \\
\hline C-75/ammonium sulphate precipitation & 16,384 & 140.4 & 16.6 & 116.7 & 1.0 & 100 \\
\hline Fractions $10-12$ /ion exchange chromatography & 1,600 & 2.7 & 36.0 & 592.6 & 5.1 & 21.2 \\
\hline Fraction $11 /$ gel filtration chromatography & 1,600 & 0.27 & 7.5 & $5,925.9$ & 50.8 & 4.4 \\
\hline Active fraction/reverse phase chromatography & 800 & 0.02 & 0.05 & $40,000.0$ & 342.8 & 0.01 \\
\hline
\end{tabular}

AU: arbitrary unit. 
and storage. None of the proteins has been described as an antagonistic substance. Among the eight proteins that exhibited $100 \%$ identity, four were described for E. coli and one for Klebsiella pneumoniae, Proteus vulgaris, Shigella flexneri and Enterobacter cloacae.

\section{DISCUSSION}

The production of bacteriocins in special colicins has been reported not only for enterobacteria, mainly E. coli, but also for other genera such as Shigella (Riley \& Wertz 2002, Cascales et al. 2007). However, most studies on $S$. sonnei colicins refer to bacteriocinotyping based on the production of and sensitivity to these substances, which is useful for epidemiological purposes and has been employed to differentiate isolates associated with shigellosis outbreaks (Abbott \& Shannon 1958, Castillo et al. 1991). To the best of our knowledge, there are few studies on the purification and characterisation of Shigella bacteriocins (Smarda et al. 1987, Smajs et al. 1997).

Among the active extracts obtained following ammonium sulphate precipitation, C-75 was selected for partial characterisation assays on the basis of the largest amount of the fraction and the highest titre of antagonistic activity. Although we selected an intracellular fraction, we believe that the antagonistic substance found in C-75 may be exported under several circumstances, such as stress. Indeed, the detection of antagonistic activity by the overlay method employing the producer bacterial strain demonstrates the secretion of antagonistic substance(s) by the organism.

The proteinaceous nature of C-75 was confirmed by its inactivation after treatment with proteolytic enzymes. The thermolability of the extract is also consistent with its chemical constitution and corroborates data reported by other authors who have demonstrated that colicins produced by Shigella are generally heat-labile (Reeves 1972, Cascales et al. 2007). Similar results were obtained for the extracellular fraction precipitated at a $75 \%$ salt concentration, as previously described by our group (Sousa et al. 2010).

In general, C-75 showed to be stable, keeping active after exposure to different $\mathrm{pHs}$ and temperatures in some cases for long periods. It should be highlighted that the aliquot maintained at $-80^{\circ} \mathrm{C}$ is still active after more than two years. Besides making studies easier stability is such a desirable characteristic for a substance that has the potential for practical applications.

C-75 bound to the Mono-Q column indicated that the protein is anionic. Although N-terminal sequencing of the substance revealed that 13 of 20 amino acids were hydrophilic, the reverse-phase chromatography results suggest that overall the protein is hydrophobic.

A low output of purified protein and a low titre of antibacterial activity were observed after completion of the sequential chromatography steps. The yield from the purification procedure clearly demonstrates that the purification procedure should be optimised to obtain significant amounts of active, purified protein.

Bacteriocins are still loosely defined antibacterial substances and the definition of specific bacteriocin cat- egories, such as colicins and microcins, is controversial. According to several authors, microcins are sized as up to $10 \mathrm{kDa}$ and although there is not a consensual determination of the colicin molecular-mass range, the smallest described substances are $40 \mathrm{kDa}, 25 \mathrm{kDa}$ or at least $20 \mathrm{kDa}$ (Pons et al. 2002, Heng \& Jack 2006, Cascales et al. 2007). The analysis of mass spectrometry data demonstrated that the purified protein obtained in the present study has an estimated molecular mass of $18.56 \mathrm{kDa}$, suggesting that the protein is a new bacteriocin that does not match any previously described bacteriocin.

The N-terminal amino acid sequence displayed identity with 20 different bacterial proteins and none of them is associated with bacterial antagonism. Their predicted function is related to DNA protection during starvation, particularly iron-binding and storage. It is interesting to highlight that unfavourable conditions, such as nutrient depletion, also stimulate bacteriocin expression (Cascales et al. 2007, Duquesne et al. 2007).

One of the eight proteins that presented $100 \% \mathrm{~N}$ terminal sequence identity (20 amino acids) with the bacteriocin described in this study is PexB, an $18-\mathrm{kDa}$, membrane-associated $E$. coli polypeptide that is induced early during starvation conditions (Almirón et al. 1992, Lomovskaya et al. 1994, Calhoun \& Kwon 2010). The structure, function and regulation of the DNA-binding protein Dps and its role in acid and oxidative-stress resistance have been determined. Considering the sequence and mass similarity and that $S$. sonnei and $E$. coli exhibit a high degree of genetic relatedness, PexB and Dps might be the same protein. However, bacteriocin activity has not been reported for PexB.

Although the antagonistic substance is not fully characterised, our results raise two possibilities: that the bacteriocin is a newly described protein or that it represents an already described protein with a newly detected function. The substance is possibly a colicin that does not fit the established molecular-mass ranges defined for colicins (at least $20 \mathrm{kDa}$ ) and microcins (no more than $10 \mathrm{kDa}$ ) (Pons et al. 2002, Heng \& Jack 2006, Cascales et al. 2007).

Colicins are an alternative mean to prevent infections associated with $E$. coli and related microorganisms. Antagonistic activity against diarrhoeagenic and uropathogenic E. coli, including the prevention of diarrhoea in livestock, has already been reported (Murinda et al. 1996, Schamberger et al. 2004, Stahl et al. 2004, Trautner et al. 2005, Cutler et al. 2007). Because $S$. sonnei SS9 exhibited antagonistic activity against other diarrhoeagenic bacteria such as $S$. flexneri and enteroinvasive E. coli (Sousa et al. 2010), this bacteriocin may contribute to bacterium virulence. Moreover, the protein has a potential clinical applicability as an alternative option for controlling and preventing diarrhoeal disease. However, before this bacteriocin can be practically applied, further studies of its structural and functional properties are mandatory.

\section{ACKNOWLEDGEMENTS}

To Luzia Rosa Rezende and José Sérgio Barros de Souza (AT/CNPq), for their technical assistance. 


\section{REFERENCES}

Abbott JD, Shannon R 1958. A method for typing Shigella sonnei using colicine production as a marker. J Clin Pathol 11: 71-77.

Abriouel H, Franz CMAP, Omar NB, Gálvez A 2010. Diversity and applications of Bacillus bacteriocins. FEMS Microbiol Rev 35: 201-232.

Almirón M, Link AJ, Furlong D, Kolter R 1992. A novel DNA-binding protein with regulatory and protective roles in starved Escherichia coli. Genes Dev 6: 2646-2654.

Baquero F, Moreno F 1984. The microcins. FEMS Microbiol Lett 23: $117-124$

Booth SJ, Johnson JL, Wilkins TD 1977. Bacteriocin production by strains of Bacteroides isolated from human feces and the role of theses strains in the bacterial ecology of the colon. Antimicrob Agents Chemother 11: 718-724.

Bradford MM 1976. A rapid and sensitive method for the quantitation of microgram quantities of protein utilizing the principle of protein-dye binding. Anal Biochem 72: 248-254.

Braun V, Patzer SI, Hantke K 2002. Ton-dependent colicins and microcins: modular design and evolution. Biochimie 84: 365-380.

Calhoun LN, Kwon YM 2010. Structure, function and regulation of the DNA-binding protein Dps and its role in acid and oxidative stress resistance in Escherichia coli: a review. J Appl Microbiol 110: 375-386.

Cascales E, Buchanan SK, Duché D, Kleanthous C, Lloubès R, Postle K, Riley M, Slatin S, Cavard D 2007. Colicin biology. Microbiol Mol Biol Rev 71: 158-229.

Castillo FJ, Carranza E, Clavel A, Rubio MC, Gomez-Lus R 1991. Epidemiology of shigellosis and colicin typing of Shigella sonnei. Enferm Infecc Microbiol Clin 9: 530-536.

Cutler SA, Lonergan SM, Cornick N, Johnson AK, Stahl CH 2007. Dietary inclusion of colicin el is effective in preventing postweaning diarrhoea caused by F18-positive Escherichia coli in pigs. Antimicrob Agents Chemother 51: 3830-3835.

Daw MA, Falkiner FR 1996. Bacteriocins: nature, function and structure. Micron 27: 467-479.

Duquesne S, Garzón D, Peduzzi J, Rebuffat S 2007. Microcins, geneencoded antibacterial peptides from enterobacterias. Nat Prod Rep 24: 708-734.

Gillor O, Giladi I, Riley MA 2009. Persistence of colicinogenic Escherichia coli in the mouse gastrointestinal tract. BMC Microbiol 9: 165 .

Green AA, Hughes W 1955. Protein fractionation on the basis of solubility in aqueous solutions of salts and organic solvents. Methods Enzymol 1: 67-90.
Heng NCK, Jack RW 2006. Microcins. In AJ Kastin, Handbook of biologically active peptides, Elsevier, Maryland Heights, p. 75-81.

Horák V 1990. Two colicins from Shigellae. Folia Microbiol (Praha) 35: 469-470

Kolter R, Moreno F 1992. Genetics of ribosomally-sinthesized peptide antibiotics. Annu Rev Microbiol 46: 141-163.

Lomovskaya OL, Kidwell JP, Matin A 1994. Characterization of the $\delta^{38}$-dependent expression of a core Escherichia coli starvation gene, pexB. J Bacteriol 176: 3928-3935.

Murinda SE, Roberts RF, Wilson RA 1996. Evaluation of colicins for inhibitory activity against diarrheagenic Escherichia coli strains, including serotype O157: H7. Appl Environ Microbiol 62: 3196-3202.

Pons AM, Lanneluc I, Cottenceau G, Sable S 2002. New developments in non-post translationally modified microcins. Biochimie 84: 531-537.

Reeves P 1972. The bacteriocins (molecular biology, biochemistry and biophysics), Spring-Verlag, New York, 142 pp.

Riley MA, Wertz JE 2002. Bacteriocin diversity: ecological and evolutionary perspectives. Biochimie 84: 357-364.

Schamberger GP, Phillips RL, Jacobs JL, Diez-Gonzales F 2004. Reduction of Escherichia coli O157: $\mathrm{H} 7$ populations in cattle by addition of colicin E7-producing E. coli to feed. Appl Environ Microbiol 70: 6053-6060.

Sharma O, Zakharov SD, Cramer WA 2006. Colicins. In AJ Kastin, Handbook of biologically active peptides, Elsevier, Maryland Heights, p. 115-123.

Smajs D, Pilsl H, Braun V 1997. Colicin U, a novel colicin produced by Shigella boydii. J Bacteriol 179: 4919-4928.

Smarda J, Petrzelova J, Vyskot B 1987. Colicin Js of Shigella sonnei: classification of type colicin "7". Zentralbl Bakteriol Mikrobiol Hyg A 263: 530-540.

Smarda J, Smajs D 1998. Colicins: exocellular lethal proteins of Escherichia coli. Folia Microbiol (Praha) 43: 563-582.

Sousa MAB, Mendes EN, Apolônio ACM, Farias LM, Magalhães PP 2010. Bacteriocin production by Shigella sonnei isolated from faeces of children with acute diarrhoea. APMIS 118: 125-135.

Stahl CH, Callaway TR, Lincoln LM, Lonergan SM, Genovese KJ 2004. Inhibitory activities of colicins against Escherichia coli strains responsible for postweaning diarrhea and edema disease in swine. Antimicrob Agents Chemother 48: 3119-3121.

Trautner BW, Hull RA, Arouiche ROD 2005. Colicins prevent colonization of urinary catheters. J Antimicrob Chemother 56: 413-415.

Yamamoto Y, Togawa Y, Shimosaka M, Okazaki M 2003. Purification and characterization of a novel bacteriocin produced by Enterococcus faecalis strain RJ-11. Appl Environ Microbiol 69: 5746-5753. 